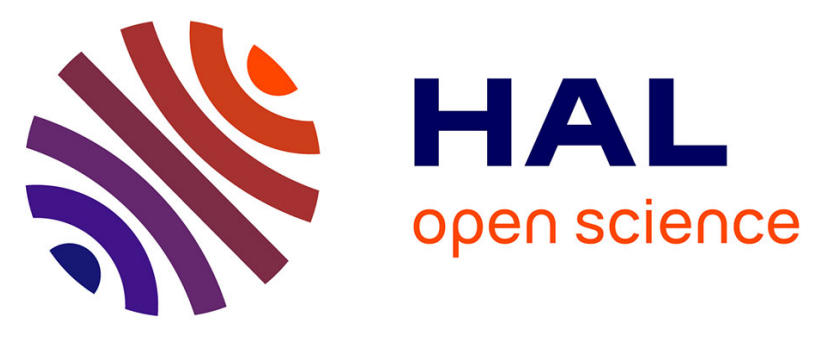

\title{
Effect of instantaneous controlled pressure drop (DIC) on physicochemical properties of wheat, waxy and standard maize starches
}

Zoulikha Maache-Rezzoug, Thierry Maugard, Ikbal Zarguili, Emmna Bezzine, Mohammed-Nadjib El Marzouki, Catherine Loisel

\section{To cite this version:}

Zoulikha Maache-Rezzoug, Thierry Maugard, Ikbal Zarguili, Emmna Bezzine, Mohammed-Nadjib El Marzouki, et al.. Effect of instantaneous controlled pressure drop (DIC) on physicochemical properties of wheat, waxy and standard maize starches. Journal of Cereal Science, 2010, 49 (3), pp.346-353. 10.1016/j.jcs.2008.10.005 . hal-00413444

\section{HAL Id: hal-00413444 https://hal.science/hal-00413444}

Submitted on 4 Sep 2009

HAL is a multi-disciplinary open access archive for the deposit and dissemination of scientific research documents, whether they are published or not. The documents may come from teaching and research institutions in France or abroad, or from public or private research centers.
L'archive ouverte pluridisciplinaire HAL, est destinée au dépôt et à la diffusion de documents scientifiques de niveau recherche, publiés ou non, émanant des établissements d'enseignement et de recherche français ou étrangers, des laboratoires publics ou privés. 
1 EFFECT OF HYDROTHERMAL TREATMENT ON PHYSICOCHEMICAL

2 PROPERTIES OF WHEAT, WAXY AND STANDARD MAIZE STARCHES

3 Authors:

4 Z. Maache-Rezzoug ${ }^{\mathrm{a}}$, T. Maugard ${ }^{\mathrm{b}}$, I. Zarguili $^{\mathrm{a}}$, E. Bezzine $^{\mathrm{b}}$, C. Loisel $^{\mathrm{c}}$, M.N. Marzouki $^{\mathrm{d}}$

6 a Laboratoire LEPTIAB, Université de La Rochelle - Pôles Sciences et Technologie,

7 Bâtiment Marie Curie, Avenue Michel Crépeau, 17042 La Rochelle, France.

8 bMR 6250 CNRS-ULR, LIENSS, Equipe Biotechnologie Environnementale,

9 Université de La Rochelle, Pôles Sciences et Technologie, Bâtiment Marie Curie,

10 Avenue Michel Crépeau, 17042 La Rochelle, France.

$11{ }^{\mathrm{c}}$ Laboratoire GEPEA, ENITIAA rue de la Géraudière, BP 82225, 44322 Nantes Cedex

123 , France.

$13{ }^{\mathrm{d}}$ Bioengineering Unit 99 UR 09-26, National Institute of Applied Sciences and

14 Technology (INSAT), BP 676 Tunis, Tunisia

$15 *$ Corresponding author.

16 E-mail address: zrezzoug@univ-lr.fr

$17 \quad$ Tél : (33) 05464587 81; Fax : (33) 0546458616 


\section{ABSTRACT}

19 Standard maize (SMS), waxy maize (WMS) and wheat (WTS) starches were 20 hydrothermally treated at three pressure levels. Effects of D.I.C. processing conditions

21 on thermal characteristics, enzyme susceptibility, pasting and rheological properties

22 were investigated. For treated starches an increase of transition temperatures $\left(T_{0}, T_{P}\right)$, a

23 narrowing of width of gelatinization endotherms and a decrease of gelatinization

24 enthalpies $(\Delta \mathrm{H})$, were observed. At $3 \mathrm{bar} / 10 \mathrm{~min} \Delta \mathrm{H}$ decreased from $11.4 \mathrm{~J} . \mathrm{g}-1$ to 1.7

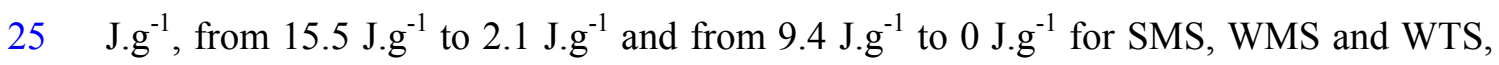
26 respectively. At same conditions, starches showed a significant increase in enzymatic 27 hydrolysis, yield of saccharification increased from $19 \%$ to $44 \%$, from $21 \%$ to $59 \%$ and 28 from $55 \%$ to $79 \%$ for SMS, WMS and WTS, respectively. The study suggested that 29 structural modifications influence in-vitro hydrolysis and the access to WMS 30 ultrastructure by enzymes seems to be easier than that of SMS. The rheological 31 behaviour was modified for treated starches: a decrease in the peak viscosity, measured 32 with a viscoamylograph Brabender, and in the apparent viscosity, measured with a 33 controlled stress rheometer, was observed.

34 Keywords: Starch; D.I.C. hydrothermal treatment; functional properties; Enzyme 35 hydrolysis 


\section{1. INTRODUCTION}

37 Starch has many applications in food and non-food industries. For this reason,

38 modifications are often made to native starches to give them specific properties for

39 particular uses. Starch properties can be modified through controlled application of heat

40 and moisture which produces physical modifications within the granules. Annealing and

41 heat-moisture treatment (HMT) cause a physical modification of starches with respect

42 to size, shape or birefringence via controlled application of heat-moisture (Stute, 1992).

43 In the annealing, starch is suspended in excess water and heated below the gelatinisation

44 temperature, at relatively low values, $\left(40-55^{\circ} \mathrm{C}\right)$ (Stute, 1992). Annealing results in

45 perfection of the crystalline properties that narrow the gelatinization temperature

46 interval by shifting them towards higher values (Hublin, 1994). Annealing does not

47 increase or only moderately the enthalpy of gelatinization (Lawal, 2005).

48 In the HMT, starch is exposed to higher temperatures $\left(\approx 120^{\circ} \mathrm{C}\right)$, commonly above 49 gelatinization temperature, at very restricted moisture content (18-30\%) during $16 \mathrm{~h}$ in

50 some cases (Hoover and Manuel, 1996) and shorter in others (Lim et al., 2001). HMT

51 has been shown to alter structure and physicochemical properties of standard maize,

52 waxy maize, amylomaize, potato, wheat (Stute, 1992; Hoover and Manuel, 1996; Lim et

53 al., 2001). The general effects of HMT on starch are the loss of the birefringence, the

54 increase of the gelatinization temperatures and the broadening of the gelatinization

55 temperature range, the increase of water bonding capacities and enzymes

56 susceptibilities, the decrease of swelling and the increase of solubility. These

57 modifications have consequences on functionality of treated starches: the viscograph hot

58 paste consistencies decrease and starch paste became short and shear-stable (Lorenz and

59 Kulp, 1982; Hoover and Manuel, 1996; Gunarante and Hoover, 2002). Hoover and 
60 Vasanthan (1994) and Hoover and Manuel (1996) have shown that the extent of

61 starch chain associations within amorphous regions and the degree of crystalline

62 order are altered during HMT of wheat, oat, normal maize, waxy maize, high amylose

63 maize, potato and lentil starches. The physical properties of heat moisture treated

64 starches depend on the starch origin and treatment conditions used (Hoover and

65 Vasanthan, 1994). Many authors showed that HMT increased the susceptibility of starch

66 to hydrolysis by $\alpha$-amylases (Kulp and Lorenz, 1982; Maruta et al., 1994; Gunaratne

67 and Hoover, 2002) and the extent of the susceptibility varies with botanical source

68 (Colonna and Buléon, 1992; Li et al., 2004; Srichuwong et al., 2005). According to

69 Lorenz and Kulp (1982) the considerable reduction in relative crystallinity of wheat

70 starch caused by HMT resulted in increased enzyme susceptibility. Planchot et al.

71 (1997) cited by Gunaratne and Hoover (2002), have postulated that the fraction of total

72 crystalline material is an important factor defining the rate and extent of $\alpha$-amylase

73 hydrolysis.

74 The D.I.C. (Détente Instantanée Contôlée: "Instantaneous Controlled pressure Drop”)

75 hydrothermal process, developed in our laboratory some years ago (Zarguili, 2006) is

76 more close to HMT. The major effects observed are almost similar except the

77 gelatinization range temperature where the D.I.C. treatment caused its narrowing

78 (Zarguili, 2006) as observed with annealing (Hublin, 1994). Preliminary studies on

79 SMS and WMS starches (Loisel et al., 2006, Zarguili et al., 2006) showed a partial or

80 total gelatinization of by D.I.C. treated starch, according to processing conditions. The

81 increase of processing time and pressure level induced the narrowing of the

82 gelatinization temperature range, the shift of the characteristics temperatures to higher

83 values and the decrease of gelatinization enthalpy. The occurrence of gelatinization of 
85 treated starches was clearly attested by the increase of median volume diameter in cold 86 water and a loss of birefringence under polarized light. Maruta et al. (1994) observed for

87 HMT treatment that the pressure is often required to ensure a sufficient heating, but it is not easy to achieve a uniform distribution and penetration of heat into the starch layer.

89 These authors improved the conventional method by the introduction of reduced 90 pressure in order to satisfy practical requirements for industrial production. They 91 observed that the combination of reduced pressure during HMT of starch allows 92 homogeneous diffusion of steam and an effective heat transfer to the starch granules. 93 During D.I.C. treatment, an initial vacuum of 50 mbar was established before 94 introducing steam in processing vessel. As demonstrated by Zarguili et al. (2006), this 95 initial vacuum allows to reduce the resistance of the air and thus to facilitate the 96 diffusion of steam into the product. Consequently, the time necessary to reach the steam 97 equilibrium temperature is reduced (Zarguili, 2006). The originality of D.I.C. method 98 compared to other physical treatments is that the starches are treated at residual 99 moisture content of $13 \%$ (dry basis) no hydration step is then used. The conventional 100 methods require previous hydration of starch before the physical treatment. During the

101 D.I.C. treatment, the starch heating is obtained by the absorption of latent heat of steam 102 condensation which causes an increase in the moisture content as the processing time 103 and pressure level increase. Changes of the moisture distribution were measured during 104 the treatment and modelled by Zarguili et al. (2007).

105 The objective of this study is to understand the physicochemical changes produced on 106 native starches after D.I.C. hydrothermal treatment. Under identical conditions 107 (processing pressure and time), the effects of D.I.C. process on the changes of thermal 
108

109 transition characteristics, enzyme digestibility, pasting and rheological properties were

110 evaluated on SMS, WMS and WTS starches. 
111

\section{2. MATERIALS AND METHODS}

113 2.1. MATERIALS

114 SMS, WMS (Waxilys 200) and WTS starches were supplied by Roquette Frères

115 (Lestrem, France). The amylose content was of 27-28\% for SMS and WTS and lower

116 than $1 \%$ for WMS. The moisture content of these starches was about $12 \%$ wet basis.

117 Fungamyl $800 \mathrm{~L}$, a $\alpha$-amylase from Aspergillus oryzae was used for starch liquefaction.

118 The enzyme activity was $800 \mathrm{FAU} / \mathrm{g}$ (1 Fungal $\alpha$-amylase FAU is the amount of 119 enzyme which breaks down $5.26 \mathrm{~g}$ of starch per hour according Novozyme's standard 120 method for the determination of $\alpha$-amylase). AMG $300 \mathrm{~L}$, a glucoamylase from 121 Aspergillus niger was used for saccharification. The enzyme activity was $300 \mathrm{AGU} / \mathrm{ml}$ 122 (1 Novo Amyloglucosidase Unit (AGU) is defined as the amount of enzyme which 123 hydrolyzes 1 micromoles maltose per minute under standardized conditions according 124 Novozymes. The enzymes were gift from Novozymes, Denmark.

125 2.2. METHODS

126 2.2.1. Moisture content

127 The starch moisture content was determined by air oven at $105{ }^{\circ} \mathrm{C}$ during $24 \mathrm{~h}$, 128 according to the A.F.N.OR standard method.

\section{2.2.2. D.I.C. hydrothermal treatment}

130 The equipment and procedure of D.I.C. hydrothermal treatment were largely described 131 in previous studies (Loisel et al., 2006; Zarguili et al., 2006). During the treatment, $22 \mathrm{~g}$ 132 of starch (13\% dry basis) disposed in circular containers (diameter: $20 \mathrm{~cm}$; height: 5 
$134 \mathrm{~cm}$ ) were placed in the treatment reactor. An initial vacuum of 50 mbar was established.

135 Saturated steam was introduced into the vessel at fixed pressure and maintained for a

136 predetermined time. In this study the processing pressure was fixed at 1 bar $\left(100{ }^{\circ} \mathrm{C}\right), 2$

137 bar $\left(122^{\circ} \mathrm{C}\right)$ and 3 bar $\left(135^{\circ} \mathrm{C}\right)$. The pressurisation is followed by an abrupt

138 decompression towards vacuum (50 mbar). After the vacuum phase, atmospheric air is

139 injected to return to atmospheric pressure for sample recovery. During the treatment,

140 starch is heated by the absorption of latent heat of vapour condensation that causes an

141 increase in the moisture content.

\section{2.2.3. Differential Scanning Calorimetry (DSC)}

143 Thermal characteristics of treated starch were studied by using a Micro DSC III

144 (SETERAM, France). Starch samples (800 mg) were placed in a stainless pan; distilled 145 water was added to get a ratio of 1:9 (w/w) starch:water, mix, and then the sample pan 146 was sealed. Sample pan was heated at a rate of $1.2{ }^{\circ} \mathrm{C} / \mathrm{min}$ from 30 to $110^{\circ} \mathrm{C}$. Thermal 147 transition of starch samples were defined as $T_{0}$ (onset temperature), $T_{P}$ (peak 148 temperature) and $\Delta \mathrm{H}$ was referred to as the gelatinization enthalpy. The gelatinization 149 temperature range (R) was calculated as $2\left(T_{p}-T_{o}\right)$ as described by Krueger et al.

150 (1987). The degree of gelatinization of treated starch was calculated by the following

151 equation (Marshall et al., 1993). DG(\%)=(1- $\left.\frac{\Delta \mathrm{H}_{\mathrm{t}}}{\Delta \mathrm{H}_{\mathrm{raw}}}\right) \times 100$, where DG is the degree

152 of gelatinization of D.I.C. treated starch, $\Delta \mathrm{H}_{\mathrm{t}}$ and $\Delta \mathrm{H}_{\mathrm{raw}}$ the gelatinization enthalpy of

153 treated and native starch, respectively. 
156 The dried samples $(300 \mathrm{mg})$ were mixed with $3 \mathrm{ml}$ of citrate phosphate buffer (pH 4.6)

157 in a $5 \mathrm{ml}$ tube. The mixture was treated with enzymes in two steps (a), liquefaction and

158 saccharification, or only in one step of saccharification (b). The first step, liquefaction,

159 was performed at $50{ }^{\circ} \mathrm{C}$ with $32 \mathrm{U} / 1(10 \mathrm{~g} / \mathrm{l})$ of Fungamyl $800 \mathrm{~L}$ for $120 \mathrm{~min}$. The

160 second step, saccharification, was performed at $65^{\circ} \mathrm{C}$ with $1.5 \mathrm{U} / 1(7 \mathrm{ml} / \mathrm{l})$ of $\mathrm{AMG} 300$

$161 \mathrm{~L}$ for $60 \mathrm{~min}$. The saccharification was performed at $65{ }^{\circ} \mathrm{C}$ with $1.5 \mathrm{U} / 1(7 \mathrm{ml} / \mathrm{l})$ of

162 AMG $300 \mathrm{~L}$ for $120 \mathrm{~min}$.

163 2.2.5. Determination of reducing equivalents

164 During the starch hydrolysis samples were withdrawn for analysis of reducing sugars 165 content using 3, 5-dinitrosalicylic acid method (DNS). In all samples, the reaction was 166 stopped by adding 1 volume of water and by heating at $100{ }^{\circ} \mathrm{C}$ for $5 \mathrm{~min}$. After 167 centrifugation of the solution at $3000 \mathrm{rpm}$ for $10 \mathrm{~min}$, a $0.5 \mathrm{ml}$ of a diluted supernatant 168 was transferred to a test tube and $0.5 \mathrm{ml}$ of DNS reagent $(10 \mathrm{~g}$ dinitrosalicylic acid +200 $169 \mathrm{ml} \mathrm{NaOH} 2 \mathrm{M}+300 \mathrm{~g}$ potassium sodium tartrate + qsp 11 distilled water) was added. The 170 tubes were allowed to stand for $10 \mathrm{~min}$ in boiling water and cooled to room temperature 171 in ice water. The absorbance of the samples was measured at $550 \mathrm{~nm}$ using a 172 spectrophotometer (Shimadzu mini UV 1240). Amount of reducing equivalents was 173 calculated using a glucose standard curve. The starch hydrolysis yield of samples was 174 calculated by:

175 Starch hydrolyse $(\%)=\left(\frac{\text { Reducing sugar expressed as glucose in sample } \mathrm{g} / 1}{\text { weight of dried starch in sample } \mathrm{g} / \mathrm{l}}\right) \times 100$ 


\section{2.2.6. Pasting properties using Viscograph Brabender}

178 The processed samples are powdery products that have to be rehydrated for analytical 179 purpose. This was performed using the Brabender Viscograph to obtain a starch paste 180 under repeatable conditions. The starch concentrations were chosen in order to lie

181 within the sensitivity range of the Viscograph: i.e. $6 \%(\mathrm{w} / \mathrm{w})$ for SMS, $4 \%(\mathrm{w} / \mathrm{w})$ for 182 WMS and 7\% (w/w) for WTS. Starch was slurried in demineralized water at room 183 temperature, and then submitted to gradual heating $\left(1.5^{\circ} \mathrm{C} / \mathrm{min}\right)$ from 30 to $96{ }^{\circ} \mathrm{C}$; this 184 temperature was maintained for $10 \mathrm{~min}$ and was followed by a cooling step $\left(1.5^{\circ} \mathrm{C} / \mathrm{min}\right)$ 185 down to $70{ }^{\circ} \mathrm{C}$ before sampling. The moisture content was determined directly after the 186 pasting procedure, to check the starch concentration before rheological measurements.

187 The relevant values obtained from the pasting profile were: onset of the pasting 188 temperature $\left(\mathrm{T}_{\mathrm{o}}\right)$, temperature of peak viscosity $(\mathrm{Tp})$ and peak viscosity $(\mathrm{PV})$ in 189 Brabender units (100 BU for $25 \mathrm{cmg}$ ).

\subsubsection{Rheological measurements}

191 Flow behaviour of starch pastes were measured using a controlled stress rheometer (TA

192 Instrument AR1000) with the cone/plate geometry $\left(6 \mathrm{~cm} / 2^{\circ}\right)$. An aliquot of the starch

193 dispersion pasted at $60{ }^{\circ} \mathrm{C}$ in the Viscograph Brabender was poured onto the plate of the

194 rheometer preheated at $60{ }^{\circ} \mathrm{C}$, then covered by a layer of paraffin oil to avoid

195 evaporation. For flow measurements, two up-down shear scans from 0.01 to $660 \mathrm{~s}^{-1}(4$

196 min each) were linearly applied, followed by a logarithmic stepwise decrease from 660

197 to $0.01 \mathrm{~s}^{-1}$, after equilibrium for each shear rate, as described by Nayouf et al., 2003.

198 Rheological properties were obtained using Herschel-Bulkley model, according to 
199 equation $\tau=\tau_{0}+\mathrm{k} \dot{\gamma}^{\mathrm{n}}$, where $\tau$ o is the yield stress (Pa), $\mathrm{k}$ the consistency index $200\left(\mathrm{~Pa} . \mathrm{s}^{\mathrm{n}}\right)$ and $\mathrm{n}$ the flow behaviour index (dimensionless). The Herschel-Bulkley model 201 fitted the data satisfactorily $\left(\mathrm{R}^{2}=0.98\right)$.

202 2.2.8. Polarised light microscopy

203 Dilute native and D.I.C. treated standard starch suspensions (1:20) were viewed under 204 polarised light (magnifying $400 \mathrm{X}$ ) using a phase contrast microscope equipped with a 205 CCD camera. 


\subsection{Thermal properties}

208 The effect of D.I.C. hydrothermal treatment on gelatinization temperatures [onset $\left(\mathrm{T}_{\mathrm{o}}\right)$, 209 peak $\left(T_{p}\right)$, and temperature range $\left.(R)\right]$ and gelatinization enthalpy $(\Delta H)$ of treated

210 starches (SMS, WMS and WTS) were studied. The obtained values were compared with

211 those of native starches. The native starches displayed differences in gelatinization

212 temperatures and enthalpy changes, as indicated by DSC analysis (Table 1). $T_{0}, T_{p}, R$

213 and $\Delta \mathrm{H}$ of SMS and SWS were higher than corresponding values for wheat. $\mathrm{T}_{\mathrm{o}}, \mathrm{T}_{\mathrm{p}}$ and

$214 \Delta \mathrm{H}$ of the native starches followed the order: WMS $>$ SMS $>$ WTS. $T_{o}$ and $T_{p}$ were of 21565.4 and $71.3 .4{ }^{\circ} \mathrm{C}$ for WMS, of 63.1 and $69.6{ }^{\circ} \mathrm{C}$ for SMS, of 50.4 and $56.6{ }^{\circ} \mathrm{C}$ for

216 WTS. According to Gunaratne and Hoover (2002), the differences in gelatinization 217 temperatures among starches can be attributed to the interplay of three factors: 218 molecular structure of amylopectin (unit chain length, extent of branching), starch 219 composition (amylose to amylopectin ratio, amount of lipid complexed, amylose chains, 220 phosphorous content) and granular architecture (crystalline to amorphous ratio). 221 Amylopectin plays a major role in starch granule crystallinity, the presence of amylose 222 lowers the melting temperature of crystalline regions and the energy for starting 223 gelatinization (Flipse et al., 1996). That explains the high gelatinization temperatures 224 and enthalpy values of WMS, which contains mainly amylopectin. Whereas Noda et al. 225 (1998) attributed the influenced of DSC parameters to the molecular architecture of 226 crystalline region, which corresponds to the distribution of amylopectin short chains and 227 not to the proportion of crystalline region which corresponds to the amylose to 228 amylopectin ratio. The gelatinization temperatures ranges $(\mathrm{R})$ of native starches (Table 229 1), calculated as $2\left(\mathrm{~T}_{\mathrm{p}}-\mathrm{T}_{\mathrm{o}}\right)$ were $13{ }^{\circ} \mathrm{C}, 11.8^{\circ} \mathrm{C}$ and $6.2^{\circ} \mathrm{C}$ for SMS, WMS and WTS, 
230 respectively. Fredriksson et al. (1998) reported that wide temperature range

231 implied a large amount of crystals with varied stability. Cooke and Gidley (1992)

232 have shown that $\Delta \mathrm{H}$ is due mainly to the disruption of the double helices rather than the

233 longer range disruption of crystallinity. Gunaratne and Hoover (2002) postulated that

234 the higher $\Delta \mathrm{H}$ values could be attributed to the presence of higher number of double

235 helices and/or weaker interaction between adjacent amylopectin double helices within

236 the crystalline domains of the native granules. The higher gelatinization parameters of

237 WMS suggest that the chains forming the doubles helices are longer with greater 238 interchain association than those of WTS.

239 For all starches, D.I.C. hydrothermal treatment increased $T_{o}$ and $T_{p}$, but decreased $R$ and

$240 \Delta \mathrm{H}$ (Table 1). $\mathrm{T}_{\mathrm{o}}$ and $\mathrm{T}_{\mathrm{p}}$ increased with increasing pressure level and processing time

241 and shifted to higher values (Fig. 1). At 2 bar $\left(122^{\circ} \mathrm{C}\right)$ and processing time of 90 min,

$242 \mathrm{~T}_{\mathrm{o}}-\mathrm{T}_{\mathrm{p}}$ shifted from $63.1-69.6{ }^{\circ} \mathrm{C}$ (native SMS) to $72.9-77.5{ }^{\circ} \mathrm{C}$, from $65.4-71.3{ }^{\circ} \mathrm{C}$

243 (native WMS) to $73.1-77.8^{\circ} \mathrm{C}$ and from $50.4-56.6{ }^{\circ} \mathrm{C}$ (native WTS) to $65.2-68.0{ }^{\circ} \mathrm{C}$.

244 At the same D.I.C. conditions $(1 \mathrm{bar} / 90 \mathrm{~min})$, the increase in $\mathrm{T}_{\mathrm{o}}\left(6.5^{\circ} \mathrm{C}\right)$ and $\mathrm{T}_{\mathrm{p}}\left(5.8^{\circ} \mathrm{C}\right)$

245 for SMS was equivalent to that observed for WTS $\left[\mathrm{T}_{\mathrm{o}}\left(7.2{ }^{\circ} \mathrm{C}\right)\right.$ and $\left.\mathrm{T}_{\mathrm{p}}\left(4.9{ }^{\circ} \mathrm{C}\right)\right]$,

246 whereas this increase was lower for WMS $\left[\mathrm{T}_{\mathrm{o}}\left(2.6^{\circ} \mathrm{C}\right)\right.$ and $\left.\mathrm{T}_{\mathrm{p}}\left(2.4{ }^{\circ} \mathrm{C}\right)\right]$. Similar

247 increases have been reported on HMT of cereal starches (Lim et al., 2001; Hoover and

248 Manuel, 1996; Hoover and Vasanthan, 1994). Lim et al. (2001) observed an increase in

$249 \mathrm{~T}_{\mathrm{o}}$ and $\mathrm{T}_{\mathrm{P}}$ from 62.6 and $66.9{ }^{\circ} \mathrm{C}$ for native maize to 63.4 and $76.7^{\circ} \mathrm{C}$, after HMT

$250\left(120^{\circ} \mathrm{C}\right.$ during 1 hour and $30 \%$ of water content). Hoover and Manuel (1996) observed a

251 large increase in $\mathrm{T}_{\mathrm{o}}, \mathrm{T}_{\mathrm{p}}$ and $\mathrm{T}_{\mathrm{c}}$ for standard maize and amylomaize $\mathrm{V}$ starches, but a

252 small increase in waxy and Dull waxy maize starches. According to these authors, the

253 change in transition temperature following HMT is probably influenced by the decrease 
254 in the destabilization effect of the amorphous regions when the starch crystallites

255 melt, due to the formation of amylose-lipid complexes and interactions between 256 and among amylose chains.

257 As discussed previously, the gelatinization temperature range (R) gives an indication of

258 the quality and heterogeneity of crystallites (Fredriksson et al., 1998; Gunaratne and

259 Hoover, 2002), R reflects the size and crystallites perfection. Many researchers have

260 already showed the broadening of the gelatinization temperature of starches after HMT

261 treatment (Hoover and Manuel, 1996; Lim et al., 2001; Adebowal et al., 2005), and this

262 broadening depends on botanical source. An inverse tendency was observed with D.I.C.

263 treated starches, a narrowing of the gelatinization temperature range for the three

264 starches, as observed with annealed starches (Hublin, 1994). A greater decrease in

265 gelatinization range was observed in SMS and WTS compared to WMS (Table 1).

266 According to Hublin (1994), the temperature range reflects the degree of cohesion

267 between crystallites, when R decreases a stronger cohesion exists between crystallites.

268 The narrower temperature range exhibited by D.I.C. treated starches suggests the 269 presence of crystallites of homogenous stability. We suppose that the D.I.C. treatment

270 allowed first the fusion of crystallites of low cohesion, which required less energy to

271 melt and a reinforcement of the interactions between the remaining crystallites chains.

272 Therefore, the residual structure after treatment contains a greater homogeneity of 273 crystallites.

274 The gelatinization enthalpies of treated starches (Tables 1 ) showed that the $\Delta \mathrm{H}$ values 275 depend on the intensity of D.I.C. conditions. The gelatinization enthalpies decreased 276 progressively for the three types of starches with increasing pressure level and 277 processing time. The extent of the decrease after treatment followed the order : 
278 WMS $>$ SMS $>$ WTS. At processing pressure of 2 bar and $90 \mathrm{~min}$, the gelatinization 279 enthalpies decrease for WTS from 9.4 (native) to $0.1 \mathrm{~J} . \mathrm{g}$-1, for SMS from 11.4 280 (native) to $7.1 \mathrm{~J}^{-1}$ and for WMS from 15.5 (native) to $11.2 \mathrm{J.g}^{-1}$. By considering 281 gelatinization degree, we noted after D.I.C. treatment ( 2 bar and $90 \mathrm{~min}$ ) a partial 282 gelatinization of $98.9 \%, 37.7 \%$ and $27.7 \%$, for WTS, SMS and WMS, respectively.

283 Vermeylen et al., 2006 observed on potato starch the decrease of gelatinisation enthalpy

284 with more severe HMT conditions, but effects of moisture content are considerable only 285 at higher temperature, between 90 and $120{ }^{\circ} \mathrm{C}$. According to Gunaratne and Hoover 286 (2002), the decrease in $\Delta H$ on HMT suggest that some of the double helices present in 287 crystalline and non crystalline regions of the granule could be disrupted under the 288 conditions prevailing during treatment. Thus, few double helices would unravel and 289 melt during gelatinization of HMT treated starches.

290 We already showed on standard maize starch (Zarguili et al., 2007) that during D.I.C. 291 treatment the moisture content of starch granules increases as pressure and processing 292 time increase, due to the absorption of accumulated steam. The initial moisture content 293 of starch $(13 \%$, base dries $)$ is different from the real moisture content present during the 294 treatment. This increase reaches an equilibrium value after a given time which depends 295 on the level of processing pressure. At the pressure of 1 and 2 bar, the equilibrium 296 moisture content was $17 \%$ and $26 \%$ (dry basis) and reached after 30 and 60 min of 297 D.I.C. treatment, respectively. However, for pressure level of 3 bar the measure of 298 equilibrium moisture content (beyond $60 \mathrm{~min}$ ) could not be taken because of the 299 formation of a compact lump making measurement difficult. From this study, at 3 bar 300 and $10 \mathrm{~min}$, the moisture content uptake was $18 \%$ (dry basis). 
302 In a first reaction, the enzyme digestibility of native WMS was compared to the

303 digestibility of two WMS treated by D.I.C. This digestibility was carried out in two 304 steps. The first step, liquefaction, was performed with Fungamyl 800 L for 120 min.

305 The second step, saccharification, was performed with AMG $300 \mathrm{~L}$ for $60 \mathrm{~min}$. The 306 kinetics of liquefaction and saccharification (not showed) of WMS treated by D.I.C. at 1

307 bar with a processing time of $90 \mathrm{~min}$ are very similar to those obtained from native

308 WMS. These results suggest that the low D.I.C. conditions (1 bar/90 $\mathrm{min})$ do not have a

309 significant effect on the enzymatic hydrolysis. It is important to note that the yield of 310 liquefaction is very low, only $10 \%$ obtained after 2 hours.

311 On the other hand, we observe that kinetics of liquefaction and saccharification but also

312 hydrolysis yields of WMS hydrotreated at 3 bar with a processing time of $10 \mathrm{~min}$ is 313 strongly improved. The liquefaction with Fungamyl involved the production of maltose 314 syrup with a little production of glucose syrup. Very fast is the rate, with a hydrolysis 315 yield around of $40 \%$ obtained in less of $10 \mathrm{~min}$. The saccharification with AMG 316 involved the production of glucose syrup, is observed by TLC analysis (Fig 2). After 1

317 hour of saccharification, a yield of hydrolysis of $80 \%$ is obtained. These first

318 experimentations demonstrate that the high D.I.C. conditions ( $3 \mathrm{bar} / 10 \mathrm{~min})$ have a big 319 effect on rates and yields of liquefaction and saccharification.

320 A similar effect was observed with saccharification without preliminary liquefaction 321 (results not showed.). A hydrolysis yield of $70 \%$ is obtained after 60 min using WMS

322 treated by D.I.C. at 3 bar/10 min, while a hydrolysis yield near of 55\% is obtained after 323130 min with WMS native. 
324 The effects of D.I.C. process on the enzymatic hydrolysis of WMS were compared 325 to those obtained on SMS and WTS starches. Saccharification alone with AMG 326 was carried out (Fig. 3), we observe that in all starches the kinetics of saccharification is 327 more efficient from treated starches than native starches. The more pronounced increase

328 in hydrolysis was observed for all starches when severe D.I.C. conditions were applied

329 (pressure level $\geq 3$ bar, table 1). The hydrolysis yield after $30 \mathrm{~min}$ of the three native 330 starches was increased after D.I.C. treatment at 3 bar for $10 \mathrm{~min}$ following the order: 331 WMS (39\%), SMS (24\%) and WTS (21\%).

332 The increase in the susceptibility towards enzymatic hydrolysis after treatment suggests 333 a strong link with the structural modifications induced by the heat treatment. The 334 increase of starch hydrolysis is concomitant with the decrease of the gelatinization 335 enthalpy. That was observed in precedent experimentations (Table 1). In a recent work 336 we showed that the D.I.C. treatment decreased the relative crystallinity of 337 hydrothermally treated starches as the severity of processing conditions increased 338 (Zarguili, 2006). The increase in the accessibility of starches to enzyme attack after

339 HMT has been also reported by several researchers (Gunaratne and Hoover, 2002).

\section{3.3. Pasting properties}

341 Typical Brabender Viscograph curves of native and D.I.C. treated starches are shown in

342 Fig. 2, of SMS, WMS and WTS. The pasting properties of analysed starches are

343 summarized in table 2. It is difficult to compare the pasting values of starches because 344 of the differences in starch concentrations used during measurements. The starch 345 concentrations were chosen in order to lie within the sensitivity range of the 346 Viscograph: i.e. $6 \%$ for SMS, $4 \%(w / w)$ for WMS and 7\% for WTS. 
347 No change in pasting temperature was observed for D.I.C. SMS at 1 bar. The peak 348 occurring at $97.5{ }^{\circ} \mathrm{C}$ and the onset of the pasting temperature at $82.5{ }^{\circ} \mathrm{C}$ for native 349 and SMS treated at 1 bar for 90 min (Table 2). The PV increased from 835 UB (native) 350 to 870 UB for SMS treated for 90 min and 1 bar. At severe D.I.C. conditions (2 bar for

$35190 \mathrm{~min}$ and 3 bar for $10 \mathrm{~min}$ ), starch produced a very soft gel which was not measurable 352 under the experimental conditions. While the pasting temperature of WMS increased 353 following D.I.C. treatment. The PV decreases with increase of the intensity of D.I.C. 354 conditions (processing pressure and time). However, at same pressure, processing time 355 seems to reduce viscosity (result not given). D.I.C. treatment decreased $T_{0}$ of WTS, 356 from $80{ }^{\circ} \mathrm{C}$ for native starch to $70{ }^{\circ} \mathrm{C}$ for D.I.C. WTS at 3 bar for $10 \mathrm{~min}$. The $\mathrm{T}_{\mathrm{p}}$ 357 remained unchanged after D.I.C. treatment. At the same D.I.C. condition (1 bar and 90 $358 \mathrm{~min}$ ) like SMS, PV of D.I.C. WTS was higher than native starch. WTS treated at 3 bar 359 for 10 min showed a cold swelling behaviour with a rapid rehydration traduced by a 360 Brabender viscosity of about 180 UB (Fig. 4). This cold viscosity is explained by a 361 partial solubilization of WTS already pregelatinized following D.I.C. treatment. 362 Compared to SMS and WTS starches, the final viscosity of WMS, that is virtually free 363 of amylose, is lower. This is probably related to the differences of amylose leaching and 364 its contribution to the setback viscosity. It well known that when gelatinized starch 365 paste is subject to cooling the extent of viscosity increase is mainly governed by the 366 rapid reassociation of linear amylose chains by formation of gel matrix.

367 Many authors have been observed that HMT increased pasting temperature 368 characteristics and decreased of Brabender pasting viscosity at $95{ }^{\circ} \mathrm{C}$ after $30 \mathrm{~min}$ 369 holding time for standard maize, amylomaize (Hoover and Manuel, 1996), potato 370 (Hoover and Vasanthan, 1994) and lentil, oat (Hoover and Vasanthan, 1994). However, 
371 for waxy maize starch heated in conventional oven, pasting properties seemed to be

372 unaffected (Hoover and Manuel, 1996). According these authors, the decrease of 373 viscosity could be explained by the increase of inter and intramolecular hydrogen bonds

374 due to the association of the amylose chains and the formation of the complex amylose-

375 lipid after hydrothermal treatment. Recent work showed by the X-ray diffraction pattern

376 of SMS D.I.C. treated at 2 bar for $60 \mathrm{~min}$ and 3 bar for 0.5 and 15 min the partial loss

377 (treatment at 2 bar) or total (treatment at 3 bar) of the crystalline structure and the

378 presence of a crystalline amylose-lipid complex formed during D.I.C. treatment

379 (Zarguili, 2006). Eliasson (1985) reported that amylose-lipid complex inhibits the

380 swelling of starch. Tester and Morrison (1990) reported also that amylopectin

381 contributes to swelling, whereas the amylose and lipids inhibits swelling.

\section{3.4. Flow properties}

383 The flow properties of native and D.I.C. SMS, WMS and WTS starch dispersions were

384 studied in the shear rate range of $0.01-660 \mathrm{~s}^{-1}$ and the results are presented in Table 2.

385 All the curves (not shown) exhibited a non-newtonian shear thinning behaviour with or

386 without a yield stress. The shear-thinning behaviour appear clearly $(\mathrm{n}<1)$, except for the

387 SMS suspensions treated at 2 bar for $90 \mathrm{~min}$ and 3 bar for $10 \mathrm{~min}$, whose rheological

388 behaviour is rather newtonian $\left(\mathrm{n}=1, \tau_{\mathrm{o}}=0\right)$. For all treated starches, one observed the

389 decrease of yield stress $\left(\tau_{0}\right)$, consistency index $(k)$, and apparent viscosity $(\eta)$ with the

390 increase in processing pressure and time. For SMS treated at 2 and 3 bar, no yield stress

391 was measured (Table 2). A drastic reduction in the apparent viscosity was observed,

392 with values close to those of water. These results confirm those obtained by the

393 Viscograph Brabender at the same D.I.C. conditions. Contrary to the SMS, the flow 
394 behaviour index of WMS remained unchanged after D.I.C. treatment, $\mathrm{n}$ was almost

395 constant and its value is approximately equal to that of the native $\operatorname{starch}(0.53)$.

396 The variation of viscosity deduced using the Herschel-Bulkley model for the three

397 starches at various D.I.C. conditions, agrees overall with pasting viscosity values

398 measured by Brabender. The reduction in viscosity after D.I.C. treatment is mainly

399 allotted to the reduction in swelling capacity of treated starches. The rheological

400 behavior of starch suspensions is known to be the result of a combination of two major

401 factors: the continuous phase and the volume fraction of dispersed phase. In the range of

402 concentrations used in this work (Loisel et al., 2006), the volume fraction appears to be

403 close to unity: the suspension can then be described as a packing of swollen starch

404 granules, the overall behavior being governed by the dispersed phase (Doublier et al., 405 1987).

\subsection{MICROSCOPIC OBSERVATIONS}

407 The polarized light microscope images (not shown) of D.I.C. treated SMS, WMS and 408 WTS starches showed that the starch granules size did not appear to have changed. At 1

409 and 2 bar for 90 min of processing time, about half of the starch granules exhibited 410 birefringence with a few swollen granules. The gradual loss of birefringence observed 411 using microscopy is also reflected in the result obtained by DSC measurements (Table

412 1). We observed that the cross polarization is still clear on a significant number of 413 granules of treated SMS and WMS. The degree of gelatinization calculated for these 414 starches were of $23.7-37.7 \%$ and $2.6-27.7 \%$, respectively. For WTS treated at 415 pressure of 2 bar and 90 min a few starch granules exhibited birefringence with little 416 swelling. The DSC measurements indicated that the starch granules were almost 417 completely gelatinized (98.9\%). At 3 bar and $10 \mathrm{~min}$, all starch granules of WST lost 
418 their birefringence. Whereas for SMS and WMS some intact granules are visible,

419 this confirms the DSC results, where the gelatinization degrees of the residual 420 structure at this condition, were of 85.1 and $86.5 \%$, respectively.

\section{4. CONCLUSIONS}

422 This study has shown that the D.I.C. treated starches gelatinise at higher temperatures 423 and over narrower temperature ranges than native starches. Moreover, gelatinization 424 enthalpies decreased progressively for the three treated starches with increasing pressure 425 level and processing time. The extent of the decrease followed this order: 426 WMS $>$ SMS $>$ WTS. The similar enzymatic behaviour was observed on D.I.C. treated 427 starches. For all starches the kinetics of saccharification was more efficient from treated 428 than native starches. The enzymatic susceptibility of starches is directly related to the 429 structural modifications produced by the hydrotraitement. The considerable reduction in 430 relative crystallinity caused by the D.I.C. treatment had as consequence the increase of 431 the enzymes susceptibility. 
433 Adebowal, K.O., Afolabi, T.A., Olu-Owolabi, B.I., 2005. Hydrothermal treatments of

434 finger millet (Eleusine coracana) starch. Food Hydrocolloids 19 (6), 974-983.

435 Colonna, P., Buléon, A., 1992. New insight on structure and properties. Page 25 in:

436 Cereal Chemistry and Technology, a long Past and a Bright Future. 9th International

437 Cereal and Bread Congress, Paris.

438 Cooke, D., Gidley, M.J., 1992. Loss of crystalline and molecular order during starch 439 gelatinization: origin of the enthalpic transition. Carbohydrate Research, 227, 13-112.

440 Donovan, J.W., 1979. Phase transitions of the starch-water system. Biopolymes, 18, $441 \quad 263-275$.

442 Doublier, J. L., Llamas, G., Le Meur, M., 1987. A rheological investigation of cereal 443 starch pastes and gels. Effect of pasting procedures. Carbohydrate Polymers, 7, 251444275.

445 Eliasson, A.C., 1985. Retrogradation of starch as measured by differential scanning 446 calorimetry. Pages 93 in: New Approaches to research on cereal Carbohydrates. R. D. 447 Hill, and L. Munck, eds. Elsevier Applied science: London.

448 Flipse, E., Keeteld, C.J.A.M., Jacobson, E., Visser, R.G.F., 1996. The dosage effect of 449 the wiltype GBSS allele is linear for GBSS activity but not for amylose content: 450 Absence of amylose has a distinct influence on the physico-chemical properties of 451 starch. Theoretical and Applied Genetics, 92, 121-127.

452 Fredriksson, H., Silverio, J., Andersson, R., Eliasson, A. -C., Aman, P., 1998. The 453 influence of amylose and amylopectin characteristics on gelatinization and 
454 retrogradation properties of different starches. Carbohydrate Polymers, 35, 119455134.

456 Gunaratne, A., Hoover, R., 2002. Effect of heat-moisture treatment on the structure and 457 physical properties of tuber and root starches. Carbohydrate Polymers, 49, 425-437.

458 Hoover, R., Manuel, H., 1996. Effect of heat-moisture treatment on the structure and 459 physicochemical properties of normal maize. waxy maize, dull waxy maize and 460 amylomaize V starches. Journal of Cereal Science, 23. 153-162.

461 Hoover, R., Vansanthan, T., 1994. Effect of heat-moisture treatment on the structure 462 and physicochemical properties of cereal. tuber. and legume starches. Carbohydrate 463 Research, 252. 33-53.

464 Hublin, L., 1994. Influence des caractéristiques structurales des amidons natifs sur leur 465 réactivité chimique. PhD dissertation, Université de Nantes. France.

466 Imberty, A., Buléon, A., Tran, V., Perez, S., 1991. Recent advances in knowledge of 467 starch structure. Starch/ Stärke, 43, 375-384.

468 Krueger, B.R., Knutson, C.A, Inglett, G. E., Walke, C.E., 1987. A differential scanning 469 calorimetry study on the effect of annealing on gelatinization behavior of corn starch. 470 Journal of Food Science, 52, 715-718.

471 Lawal, O.S., 2005. Studies on the hydrothermal modifications of new cocoyam 472 (Xanthosoma sagittifolium) starch. International journal of biological macromolecules, $473 \quad 37(5), 268-277$.

474 Li, J.H., Vasanthan, T., Hoover, R., Rossnagel, B.G., 2004. Starch hull-less barley: IV. 475 Morphological and structural changes in waxy, normal and high-amylose starch 
476 granules during heating. Food Research International, 37, 417-428.

477 Lim, S.T., Chang, E.H., Chung, H.J., 2001. Thermal transition characteristics of heat-

478 moisture treated corn and potato starches. Carbohydrate Polymers, 46, 107-115.

479 Loisel, C., Maache-Rezzoug, Z., Esneault, C., Doublier, J.L., 2006. Effect of 480 hydrothermal treatment on the physical and rheological properties of maize starches. 481 Journal of Food Engineering, 73, 45-54.

482 Lorenz, K., Kulp, K., 1982. Cereal and root starch modification by heat-moisture 483 treatment. I. physicochemical properties. Starch/ Stärke, 34, 50-54.

484 Marshall, W.E., Wadsworth, JI., Verma, L.R., Velupillai, L., 1993. Determining the 485 degree of gelatinization in parboiled rice: comparison of subjective and an objective 486 method. Cereal Chemistry, 70, 226-230.

487 Maruta, I., Kurahashi, Y., Takayano, R., Hayashi, K., Yoshino, Z., Komaki, T., Hara, 488 S., 1994. Reduced-pressurized heat-moisture treatment. A new method for heat489 moisture treatment of starch. Starch/Stärke, 46, 177-181.

490 Noda, T., Takahata, Y., Sato, T., Suda, I., Morishita, T., Ishiguro, K., 1998.

491 Relationships between chain length distribution of amylopectinand gelatinization 492 properties within the same botanical origin for sweet potato and buckwheat. 493 Carbohydrate Polymers, 37, 153-158.

494 Planchot, V., Colonna, P., Buléon, A. Gallant, D., 1997.Amylosis of starch granules and 495 a-glucan crystallites. In R. J. Frazier, A. M. Donald \& P. Richmond, Starch structure 496 and functionality (PP. 141-152). Cambridge, UK : Royal Society of Chemistry.

497 Srichuwong, S., Sunarti, T.C., Mishima, T., Isono, N., Hisamatsu, M., 2005. Starches 
498 from different botanical sources II: Contribution of starch structure to swelling and 499 pasting properties. Carbohydrate Polymers, 62, 25-34.

500 Stute, H., 1992. Hydrothermal modification of starches: the difference between

501 annealing and heat-moisture treatment, Starch/Stärke, 44, 205-214.

502 Tester, R.F., Morrison, W.R., 1990. Swelling and gelatinization of cereal starches. I.

503 Effects of amylopectin, amylase and lipids. Cereal chemistry, 67, 551-557.

504 Vermeylen, R., Goderis, B., Delcour, J.A., 2006. An X-ray study of hydrothermally 505 treated potato starch. Carbohydrate Polymer, 64, 364-375.

506 Zarguili, 2006. Etude de l'effet de 1'hydrotraitement D.I.C. sur les propriétés 507 structurales et fonctionnelles des amidons de différentes origines botaniques. PhD 508 dissertation, Université de La Rochelle. France

509 Zarguili, I., Maache-Rezzoug, Z., Loisel, C., Doublier, J.-L., 2006. Influence of D.I.C. 510 hydrothermal process conditions on the gelatinization properties of standard maize 511 starch. Journal of Food Engineering, 77 (3), 454-461.

512 Zarguili, I., Maache-Rezzoug, Z., Loisel, C., Doublier, J.-L., 2007. A mathematical 513 model to describe the change of moisture distribution in maize starch during D.I.C. 514 hydrothermal treatment. International Journal of Food Science and Technology, in 515 press. 
Table 1. DSC characteristics of native and D.I.C. treated starches, of SMS, WMS and WTS starches, at various steam pressures level and processing time. Hydrolysis yield after $30 \mathrm{~min}$ of saccharification with AMG.

\begin{tabular}{|c|c|c|c|c|c|c|c|}
\hline \multirow[b]{2}{*}{$\begin{array}{l}\text { Starch } \\
\text { source }\end{array}$} & \multirow[b]{2}{*}{$\begin{array}{l}\text { D.I..C. } \\
\text { treatment }\end{array}$} & \multicolumn{5}{|c|}{ Gelatinization parameters } & \multirow[b]{2}{*}{$\begin{array}{l}\text { Hydrolysis } \\
\text { yield }(\%)\end{array}$} \\
\hline & & $\begin{array}{l}\mathrm{T}_{\mathrm{o}} \\
\left({ }^{\circ} \mathrm{C}\right)\end{array}$ & $\begin{array}{l}\mathrm{T}_{\mathrm{p}} \\
\left({ }^{\circ} \mathrm{C}\right)\end{array}$ & $\begin{array}{l}\mathrm{R} \\
\left({ }^{\circ} \mathrm{C}\right)\end{array}$ & $\begin{array}{l}\Delta \mathrm{H} \\
(\mathrm{J} / \mathrm{g})\end{array}$ & $\begin{array}{l}\text { DG } \\
(\%)\end{array}$ & \\
\hline \multirow[t]{4}{*}{ SMS } & Native & $63.1 \pm 0.4$ & $69.6 \pm 0.5$ & 13.0 & 11.4 & 0.0 & 19 \\
\hline & $1 \mathrm{bar} / 90 \mathrm{~min}$ & $69.6 \pm 0.2$ & $75.4 \pm 0.4$ & 11.6 & 8.7 & 23.7 & nd \\
\hline & $2 / \mathrm{bar} / 90 \mathrm{~min}$ & $72.9 \pm 0.6$ & $77.5 \pm 0.8$ & 9.2 & 7.1 & 37.7 & nd \\
\hline & $3 \mathrm{bar} / 10 \mathrm{~min}$ & $74.8 \pm 0.9$ & $79.8 \pm 0.7$ & 10.0 & 1.7 & 85.1 & 1.7 \\
\hline \multirow[t]{4}{*}{ WMS } & Native & $65.4 \pm 0.9$ & $71.3 \pm 0.9$ & 11.8 & 15.5 & 0.0 & 15.5 \\
\hline & $1 \mathrm{bar} / 90 \mathrm{~min}$ & $68.0 \pm 0.7$ & $73.7 \pm 0.6$ & 11.4 & 15.1 & 2.6 & nd \\
\hline & $2 \mathrm{bar} / 90 \mathrm{~min}$ & $73.1 \pm 0.9$ & $77.8 \pm 0.8$ & 9.5 & 11.2 & 27.7 & nd \\
\hline & $3 \mathrm{bar} / 10 \mathrm{~min}$ & $75.2+0.2$ & $77.9 \pm 0.3$ & 5.4 & 2.1 & 86.5 & 2.1 \\
\hline \multirow[t]{4}{*}{ WTS } & Native & $50.4 \pm 0.2$ & $56.6 \pm 0.2$ & 6.2 & 9.4 & 0.0 & 9.4 \\
\hline & $1 \mathrm{bar} / 90 \mathrm{~min}$ & $57.6 \pm 0.5$ & $61.5 \pm 0.5$ & 3.9 & 8.0 & 14.9 & nd \\
\hline & $2 \mathrm{bar} / 90 \mathrm{~min}$ & $65.2 \pm 0.3$ & $68.0 \pm 0.3$ & 2.8 & 0.1 & 98.9 & nd \\
\hline & $3 \mathrm{bar} / 10 \mathrm{~min}$ & - & - & - & 0.0 & 100 & 0.0 \\
\hline
\end{tabular}

$\mathrm{T}_{\mathrm{o}}$ : onset temperature; $\mathrm{T}_{\mathrm{p}}$ : peak temperature. Temperature values are means of triplicate determinations \pm standard deviation. $\mathrm{R}$ : temperature range calculated as $2\left(\mathrm{~T}_{\mathrm{p}}-\mathrm{T}_{\mathrm{o}}\right) . \Delta \mathrm{H}$ : enthalpy of gelatinization with the mean absolute error (three repetitions) of $0.5 \mathrm{~J} / \mathrm{g}$. DG: degree of gelatinization. nd: not determined. 
Table 2. Pasting and rheological characteristics of native and D.I.C. treated starches at pressure of 1, 2 and 3 bar for two processing time.

\begin{tabular}{|c|c|c|c|c|c|c|c|c|}
\hline \multirow{2}{*}{$\begin{array}{l}\text { Starch } \\
\text { source }\end{array}$} & \multirow{2}{*}{$\begin{array}{l}\text { D.I.C. } \\
\text { treatment }\end{array}$} & \multicolumn{3}{|c|}{ Pasting properties } & \multicolumn{4}{|c|}{ Rheological properties } \\
\hline & & $\mathrm{T}_{0}\left({ }^{\circ} \mathrm{C}\right)$ & $\mathrm{T}_{\mathrm{p}}\left({ }^{\circ} \mathrm{C}\right)$ & $\mathrm{PV}^{\mathrm{d}}(\mathrm{UB})^{\mathrm{e}}$ & $\tau_{\mathrm{o}}(\mathrm{Pa})$ & $\mathrm{K}\left(\mathrm{Pa} \cdot \mathrm{s}^{\mathrm{n}}\right)$ & $\mathrm{n}$ & $\eta$ (Pa.s) \\
\hline \multirow[t]{4}{*}{$\mathrm{SMS}^{\mathrm{a}}$} & native & 82.5 & 97.5 & 835 & 2.28 & 1.39 & 0.57 & 3.68 \\
\hline & $1 \mathrm{bar} / 90 \mathrm{~min}$ & 82.5 & 97.5 & 870 & 1.25 & 0.82 & 0.57 & 2.07 \\
\hline & $2 \mathrm{bar} / 90 \mathrm{~min}$ & - & - & 0 & 0.00 & 0.00 & 1.00 & 0.00 \\
\hline & $3 \mathrm{bar} / 10 \mathrm{~min}$ & - & - & 0 & 0.00 & 0.00 & 0.99 & 0.00 \\
\hline \multirow[t]{4}{*}{$\mathrm{WMS}^{\mathrm{b}}$} & native & 72.5 & 83.0 & 640 & 0.70 & 0.88 & 0.53 & 1.58 \\
\hline & $1 \mathrm{bar} / 90 \mathrm{~min}$ & 77.5 & 88.5 & 625 & 0.18 & 0.33 & 0.57 & 0.52 \\
\hline & $2 \mathrm{bar} / 90 \mathrm{~min}$ & 82.0 & 90.0 & 400 & 0.16 & 0.18 & 0.63 & 0.35 \\
\hline & $3 \mathrm{bar} / 10 \mathrm{~min}$ & 81.0 & 88.5 & 490 & 0.17 & 0.27 & 0.59 & 0.45 \\
\hline \multirow[t]{4}{*}{$\mathrm{WTS}^{\mathrm{c}}$} & native & 80.0 & 97.5 & 562 & 0.95 & 0.44 & 0.78 & 1.39 \\
\hline & $1 \mathrm{bar} / 90 \mathrm{~min}$ & 77.5 & 97.5 & 640 & 0.96 & 0.45 & 0.82 & 1.42 \\
\hline & $2 \mathrm{bar} / 90 \mathrm{~min}$ & 75.0 & 97.5 & 400 & 0.55 & 1.90 & 0.59 & 2.46 \\
\hline & $3 \mathrm{bar} / 10 \mathrm{~min}$ & 70.0 & 97.5 & 385 & 0.00 & 0.03 & 0.89 & 0.03 \\
\hline
\end{tabular}

${ }^{\mathrm{a}} 6 \%(\mathrm{w} / \mathrm{w})$ aqueous standard maize starch suspension; ${ }^{\mathrm{b}} 4 \%(\mathrm{w} / \mathrm{w})$ aqueous waxy maize starch suspension; ${ }^{\mathrm{c}}$ $7 \%(\mathrm{w} / \mathrm{w})$ aqueous wheat starch suspension; $\mathrm{T}_{0}$ : onset of the pasting temperature ${ }^{\mathrm{d}} \mathrm{PV}$, peak viscosity. ${ }^{\mathrm{e}} \mathrm{UB}$, Units Brabender. $\tau_{0}$ :yield stress ; $\mathrm{K}$ : consistency index; $\mathrm{n}$ : flow behaviour index ( $\mathrm{K}$ and $\mathrm{n}$ were determined from Herschel-Bulkley model); $\eta$ :apparent viscosity measured for shear rate of $1 \mathrm{~s}^{-1}$. 


\section{Figure captions}

Fig. 1. Differential scanning calorimetry curves of native and DIC treated standard maize (SMS), waxy maize(WMS) and wheat(WTS) starches at processing time of 90 and 10 min and pressure level of $1\left(100^{\circ} \mathrm{C}\right), 2\left(122^{\circ} \mathrm{C}\right)$ and 3 bar $\left(135^{\circ} \mathrm{C}\right)$.

Fig. 2. TLC analysis of WMS hydrolysis. Native WMS after $20 \mathrm{~min}$ of Liquefaction (A), treated WMS at $3 \mathrm{bar} / 10 \mathrm{~min}$ after 20 min of Liquefaction (B), native WMS after 120 min of Liquefaction and 60 min of saccharification (C) treated WMS at $3 \mathrm{bar} / 10 \mathrm{~min}$ after $120 \mathrm{~min}$ of Liquefaction and $60 \mathrm{~min}$ of saccharification (D).

Fig. 3. Time course of several starches hydrolysis by AMG. WMS native (•), WMS treated by DIC at $3 \mathrm{bar} / 10 \mathrm{~min}(\mathrm{O})$, WTS native ( $\boldsymbol{\square})$, WTS treated by DIC at $3 \mathrm{bar} / 10 \mathrm{~min}$ $(\square)$, SMS native $(\Delta)$ and SMS treated by DIC at $3 \mathrm{bar} / 10 \mathrm{~min}(\triangle)$.

Fig. 4. Brabender curves of native and DIC treated SMS, WMS and WTS. 
Fig. 1
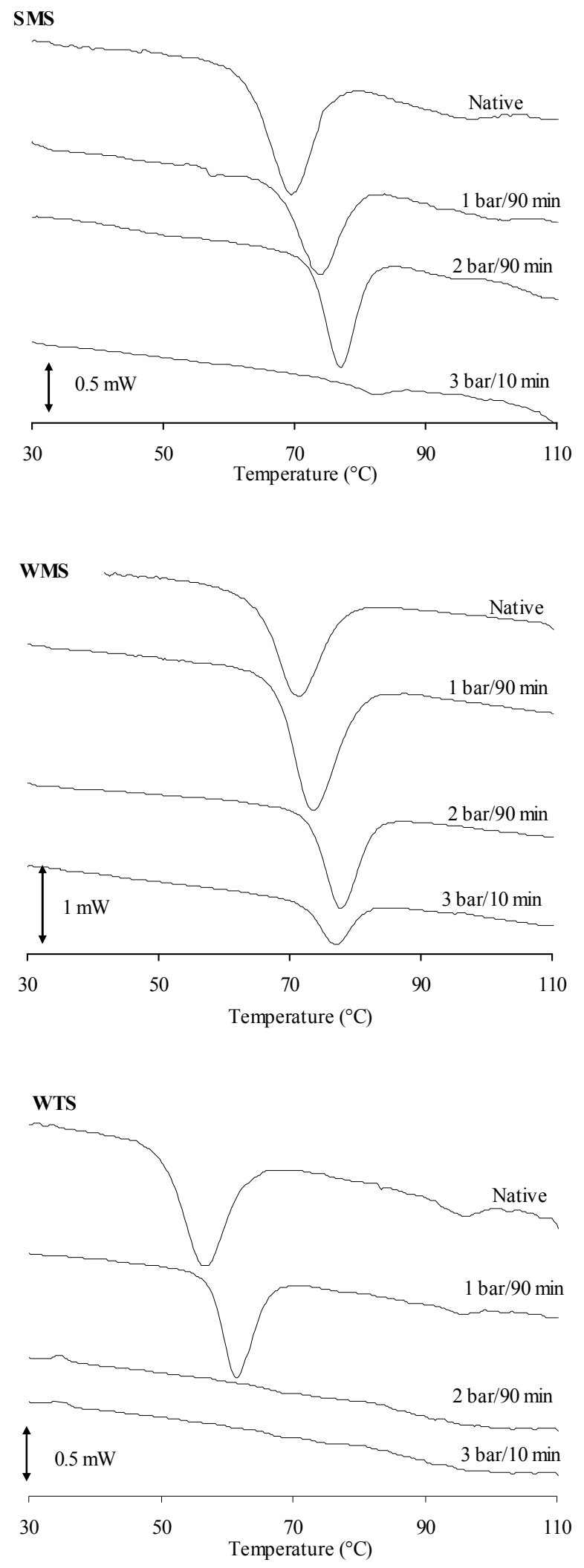
Fig. 2

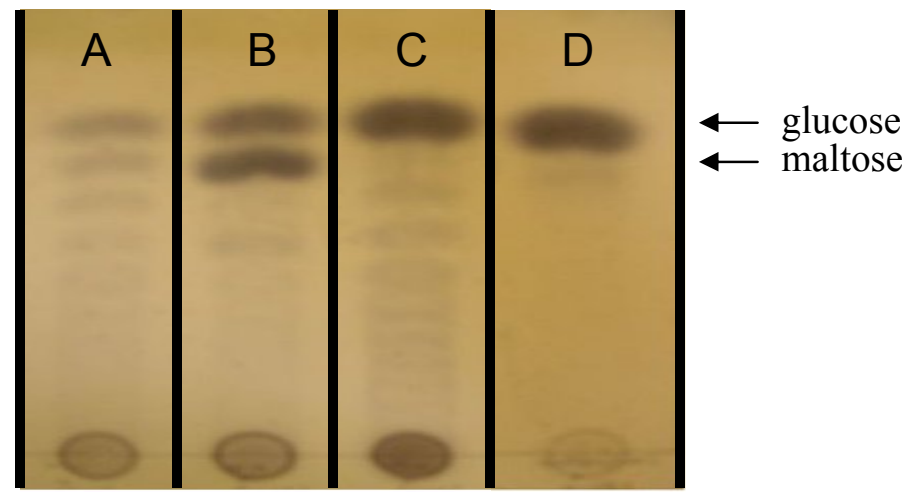

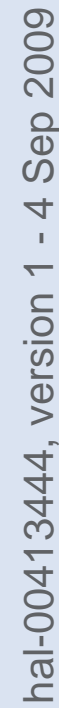


Fig. 3

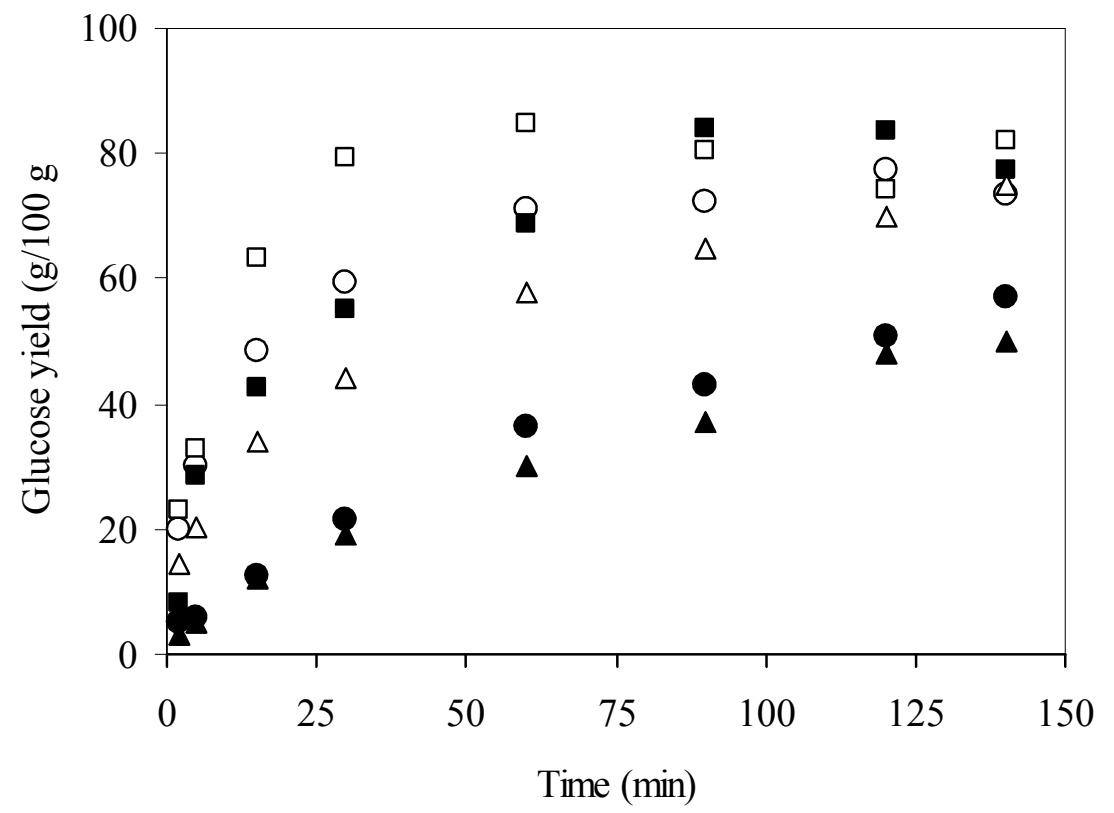


Fig. 4
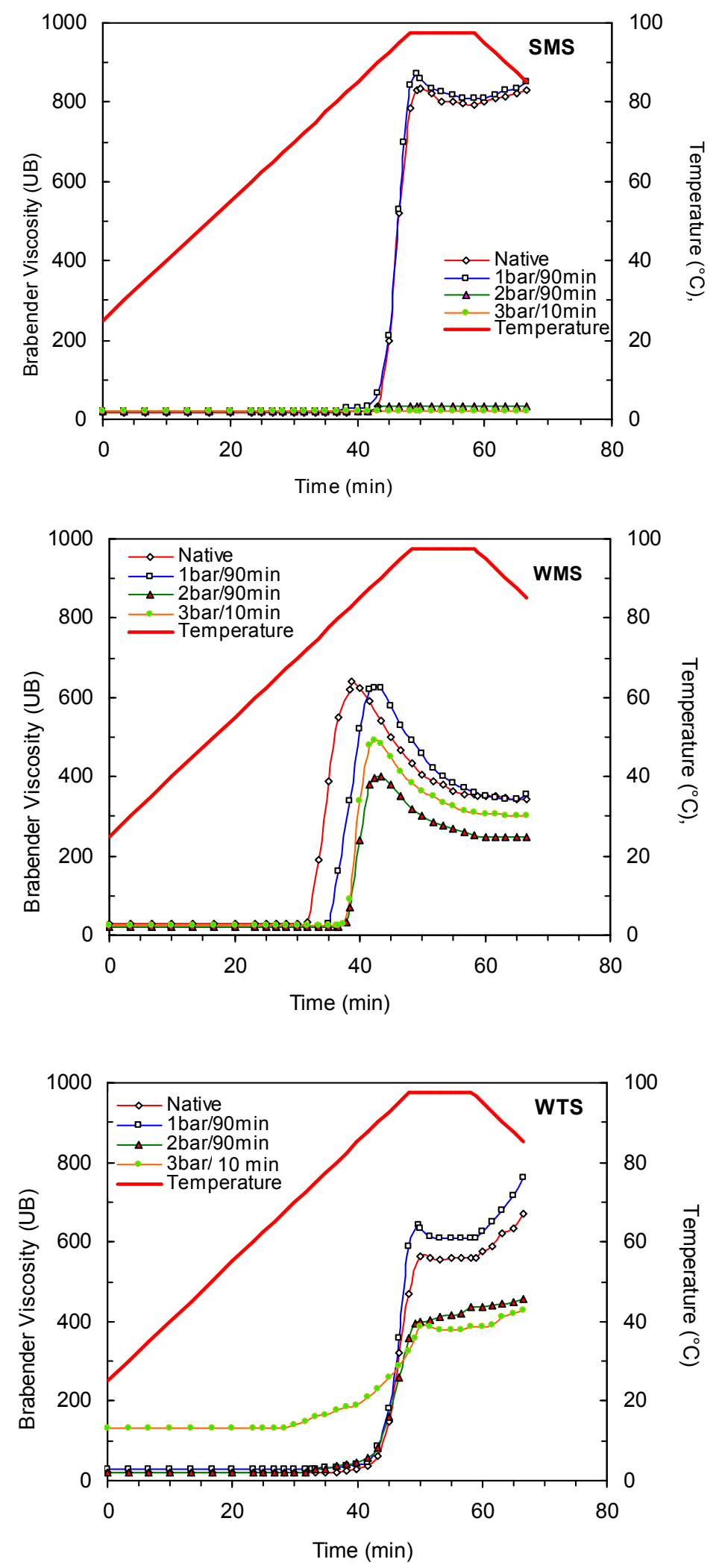